\title{
The economic effects of suckling and milk feeding to calves in dual purpose dairy and beef farming
}

\author{
Leif Jarle Asheim $^{1}$ • Julie Foske Johnsen ${ }^{2}$ Ø Øystein Havrevoll ${ }^{3}$ - Cecilie Marie Mejdell ${ }^{2}$. \\ Ann Margaret Grondahl ${ }^{2,4}$
}

Received: 15 December 2014 / Accepted: 18 January 2016/Published online: 3 June 2016

(C) INRA and Springer-Verlag France 2016. This article is published with open access at Springerlink.com

\begin{abstract}
The study examines the economics of different calf rearing systems and considers effects of suckling and milk feeding on production, health and welfare of dairy cows and growth, milk and feed use, health and welfare of calves. The economics of (i) no suckling, (ii) suckling for 3 days, (iii) suckling for 7 weeks, all assuming milk or milk replacer fed until weaning at 13 weeks, was compared with (iv) suckling for 13 weeks and no milk feeding. A linear programming (LP) model, maximizing profit on a dual purpose dairy-beef farm in lowland eastern Norway, was used for the comparison. Details on calf rearing methods, labor, weaning age, intake of milk, and solid feed were gathered for a sample of organic farms and grouped according to the length of the suckling period. The data were coupled with the National Dairy Herd Recording System (NDHRS) using cross-sectional data for the years 2008-2013. The results of the model study showed that suckling up to at least 7 weeks and longer than on most farms in the survey, had a positive influence on the farm economics. This was due to the positive influence on calf growth and health as well as lowered costs. Consequently, dual purpose dairy-beef farmers should be careful to sacrifice calf suckling and restrict calf milk feeding. Long suckling until weaning at 13 weeks was, however, unprofitable.
\end{abstract}

Leif Jarle Asheim

leif-jarle.asheim@nibio.no

1 Norwegian Institute of Bioeconomy Research, N-1431 Ås, Norway

2 Norwegian Veterinary Institute, N-0106 Oslo, Norway

3 Nortura Rudshøgda, N-2360 Rudshøgda, Norway

4 Norwegian University of Life Sciences, N-1432 Ås, Norway
Keywords Calfgrowth · Nursing $\cdot$ Milk ration · Profitability · Health $\cdot$ Animal welfare

JEL Classification Q12 · Q18

\section{Introduction}

Prevention of suckling by early separation of cow and calf, which is commonly practiced in the dairy industry today, might be seen as a sacrifice of animal's naturalness for production purposes (Boogaard et al. 2008), and has been questioned from the perspective of animal welfare (von Keyserlingk and Weary 2007). Allowing for a period of suckling may thus be perceived by consumers or the society as a more animal friendly and sustainable way of raising calves and producing milk. Although consumer concern for animal welfare is increasing, the food industries possess few mechanisms for public engagement (Ventura et al. 2013). In Norway, the Animal Protection Alliance and the Norwegian Council for Animal Ethics (1997) have been concerned about the practice of early cow-calf separation. Also, according to the Norwegian Governmental white book on Animal Welfare (Det kongelige landbruksdepartement 2002), farming systems allowing calves and cows to be in contact for a period after birth should be adapted. Tradition has likely been an important reason for the early cow-calf separation practice; however, economics might also influence the decision. If more natural systems allowing for maternal behavior are to become customary, they need to be profitable due to lower costs or consumers being willing to pay more for such production. This makes a study of the economics of suckling an important research task in dairy farming.

Most Norwegian, organic and non-organic, dairy farmers have a dairy-beef production system selling the milk and 
raising the calves for replacement or beef. The common cattle breed Norwegian Red (NRF) is bred for both milk and beef yields. However, milk production is usually given priority over beef production and suckling may be considered unprofitable. Because suckling calves drink large amounts of milk, more cows and a higher work load would be required to fill the milk quota. On the other hand, more cows result in more calves that can be raised and slaughtered because there is no quota for meat. Moreover, suckling saves work associated with calf milk feeding and animal welfare is likely improved compared to, e.g., raising the calves in single-pens. Suckling calves may grow very well (Grøndahl et al. 2007), and when the animals are ready for slaughtering or calving at a younger age, costs on maintenance feed as well as housing and labor costs are saved. There are indications that early high milk intake in calves results in a higher milk yield in the first lactation (Shamay et al. 2005) and several studies confirm that a high body weight for heifers at calving had a positive effect on milk production in the first lactation (Langhout and Wagenaar 2006; Bar-Peled et al. 1997; Terré et al. 2009). In non-organic dairy operations, calves are fed approximately $6 \mathrm{~L} /$ day of either fresh or acidified whole milk or milk replacer based on powder for 6-8 weeks (ca $300 \mathrm{~L}$ in total). However, recent research has indicated that calves at this age respond well when consuming 10-12 L milk/day (Khan et al. 2011; Jasper and Weary 2002). Restricted milk feeding may result in impaired growth and development as well as poorer animal welfare. Feeding high levels of milk may improve calf health and cow performance (Grøndahl et al. 2007; Moallem et al. 2010; Soberon et al. 2012).

The risks of calf diseases and mortality, which may differ depending on whether the calf suckles the cow or is reared artificially, will also affect the economic viability of the management system. As for the dairy cows, one needs to distinguish between short and long term effects. Short term risks of mastitis and some other diseases on the dam may be lowered due to suckling in the colostrum period or longer (Krohn 2001). Costs due to mastitis in particular may be substantial involving costs for veterinary service and medicine, foregone income due to the withholding of milk, increased work load as well as a risk of permanently lowered production from the affected quarter. Another negative short-term effect is that oestrus may be postponed due to suckling, resulting in longer calving intervals which influence annual milk yield (Stagg et al. 1998). Krohn et al. (1990) found that restricted suckling increased the interval until first heat from 31 to 44 days, but did not affect the number of empty days. Carruthers and Hafs (1980) found similar results with free suckling. Moss and O'Grady (1978) found no effects on fertility of free or restricted suckling in early lactation. Although suckling may postpone the first oestrus, the studies indicated that suckling did not seem to lengthen the calving interval much, because of relatively high cow fertility after the calves were removed.
Also, work by Piccinali and Monje (2000) indicated no impact of suckling on fertility, at least not when suckling was increased from 30 to 60 days in Argentinian suckler-cow systems. The short inter-calving interval with minimum influence on average pregnancy rate makes suckling an important technique in intensive cow breeding schemes in Argentina.

As for the milk quality, the fat content of the saleable milk is reported to be reduced by about $1 \%$ due to suckling (Zipp et al. 2013). This effect should likely disappear when the calf is removed. The effect on the milk fat content is also depending on when suckling takes place, before or after milking, as the first milk has a lower fat content (Combellas and Tesorero 2003). In a longer run, two or more years, heifer calves that were allowed to suckle may have increased robustness and enhanced economic life time, resulting in lower costs of replacement. Bar-Peled et al. (1997) reported that such cows were larger compared to cows fed from buckets as calves. The improved health and robustness may also result in improved milk quality such as lower cell counts and perhaps also higher protein content (Lidfors and Johansson 2006). The Norwegian dairy industry pays about the same premium for each 0.1 percentage point change in milk protein and milk fat content over a reference value due to its higher value in cheese and cream production.

Finally, dairy farmers may take pride in their animals and find their job more interesting when they are fulfilling high standards of animal welfare. In Norwegian organic dairy production, it is mandatory to allow the calf to suckle the dam during the first 3 days in the colostrum period. In organic farms, all young mammals shall be fed on natural milk for a minimum of 3 months (FOR 2005) $)^{1}$ and suckle or drink from a nipple the first month. While the minimum of 3 days suckling period is practiced by most producers, some may skip this and start milk feeding right after birth while others may opt for longer suckling periods. This makes organic dairy farmers a relevant group for studying effects of suckling at the farm level.

The purpose of the study is to compare the profitability of different calf feeding strategies on dual purpose dairy-beef farms. The comparison takes into account differences due to milk feeding intensity regarding growth rate and milk performance, health and welfare of calves, heifers and cows, affecting the economic performance of the farms. The key management question is how much milk the farmer decides to provide to the calf. Both the amount of milk and how the milk is fed are important for the performance and welfare of cows and calves. A strategy with lower growth rates due to limiting amounts of milk is compared with suckling, and consequently

\footnotetext{
${ }^{1}$ In the European Union (EU) there is no similar suckling requirement, however farmers are required to use whole milk and milk powder for three months, skim milk or whey is not permitted (Article 20 COMMISSION REGULATION (EC) No 889/2008 of 5 September 2008).
} 
higher milk intakes, to enhance the calf growth. The highest growth rate is achieved by comprehensive use of milk following suckling of the dam for an extended period. Suckling for an extended period also allows a more natural motheroffspring relationship during that period. For all strategies, it is important to ensure an easy transition to solid feed for the calf and it can be achieved by limiting the intake of milk during the pre-ruminant stage. However, the calf may also learn to eat roughage by imitating the dam. The strategies with suckling for an extended period for higher welfare levels at the costs of more milk were not seen upon as an obstacle for later intake of solid feed.

\section{Materials and methods}

\section{The survey data}

Due to the special Norwegian regulations for organic dairy farms requiring minimum 3 days of suckling, we draw on survey data from organic farms for the study (Ellingsen et al. 2015). The data were derived from two Questback ${ }^{\mathrm{TM}}(\mathrm{QB})$ questionnaires. In 2009, a short form (QB1) was distributed to all $(N=336)$ registered Norwegian organic dairy farmers both by email and post, and 236 answers $(70 \%)$ were received. Farmers were asked if the calves suckled the dam and for how many days or weeks after birth. They were also asked if they were willing to participate in a consecutive, extensive survey (QB2) regarding calf rearing, farm economics and animal welfare. QB2 was distributed to 157 farmers during the fall/winter of 2011, and $83(53 \%)$ responded. Prior to distribution, the questionnaires were tested, and QB1 and QB2 took 15 and $25 \mathrm{~min}$ respectively to complete.

In QB2, farmers were asked how milk feeding was carried out in the colostrum period, the rest of the first week, and in the subsequent 2 weeks periods up to the weeks 11-12, reflecting the farm practice over several years. Seven farms reporting that the calf was suckling the dam for at least 2 weeks were placed in a long suckling group. The average length of the suckling period in this group was roughly estimated to 5 6 weeks as all allowed suckling the dam in the weeks $2-3$ but only a third in the weeks 11-12. Moreover, 14 farms reporting that the calf did not suckle the dam or foster cow, were selected for a no suckling group. A remaining 56 farms were in a short suckling group assumed to be suckling for 3 days postpartum.

The survey data in QB1 and QB2 were coupled with the central database of the National Dairy Herd Recording System (NDHRS), managed by TINE Norwegian Dairies (TINE 2013), using data for the years 2008-2012. Around $98 \%$ of the herds participate in the NDHRS, which obtains data regarding growth, performance, and economics from farmers and slaughterhouses. The health data in NDHRS were obtained from the Norwegian Cattle Health Recording System
(NCHRS). Participation in the NCHRS is mandatory, and farmers and practicing veterinarians report diseases and preventive treatments for each animal there.

The coupling of the databases with the questionnaire revealed that the number of cows averaged 15 in the long suckling group, compared to 23-24 in the short or no suckling groups. Milk deliveries per cow were also lower in the long suckling group. The data may reflect that a low milk quota influence a decision to opt longer suckling. In general, the inquired farmers were very positive to practice suckling, and emphasized improved growth, robustness, and general health and well-being of suckling calves. Among the farmers practicing suckling, $73 \%$ reported that they perceived the calf to be more robust when allowed to suckle the dam beyond the colostrum period, and only $5 \%$ disagreed. However, $18 \%$ were unsure, mentioning, e.g. udder problems. Most farmers (92\%) reported that they milked the cow during the suckling period.

\section{Farm model}

The economics of different suckling and milk feeding systems to calves was investigated in a linear programming (LP) farm model, based on maximization of total gross margin (TGM). Given a milk quota system, one might choose to minimize the costs of production for the milk quota; however, since farmers also produce beef, it might be profitable to have more cows and calves to increase beef production. This can be investigated in a maximization model. The mathematical model of a primal LP problem is given by the equation:

Max $Z=c^{\prime} x$, subject to $A x \leq b, x \geq 0$.

Here $Z$ is the farmer's objective function in this case the total gross margin (TGM), i.e., the returns from livestock production, government payments, minus variable costs; $x$ is a vector of activity levels; $c^{\prime}$ a vector of marginal net returns per unit of each activity. The fixed costs, depending on alternative, were subtracted from the TGM to arrive at farm profit. $A$ is a matrix of technical coefficients showing resource requirements by the activities; $b$ is the vector of right-hand side values of resources (e.g., land, labor, milk quota). The challenge is to identify the composition of activities resulting in the maximum objective function value, not violating any constraints $(A x \leq b)$, or involving any negative activity levels $(x \geq 0)$.

The model was based on a model used in Asheim et al. (2014) for rural areas of south Norway which was adapted to 3 years (2010-12) average data from dairy-beef farms located in the central lowland grain areas of south eastern Norway. These data encompass resources of farm area, family workforce, milk quota etc. and were collected from the farm account database of the Norwegian Agricultural Economics 
Research Institute (NILF 2013a). The farm area was 41 ha which was used for leys for silage or pasture for the dairy herd, and for cereal crops. Due to a longer growing season, the net yields of leys and pasture were assumed to be $7 \%$ higher than in the previous model (Table 1 in Asheim et al. 2014) for the same amounts of manure and mineral fertilizers. The silage was baled and the costs of fertilizers and baling represented roughly $75 \%$ of the variable costs for silage.

Standard feeding based on energy, protein, and roughage dry matter $(\mathrm{DM})$ requirements for milk, foetus, growth and maintenance, depending on weight, were applied for cows and after weaning of calves. Energy was specified as Feeding Units Milk (FEm) with $1 \mathrm{FEm}$ equal to 6.9 megajoule (MJ) of Net Energy Lactation (NEL). Protein was specified in kilogram Amino Acids absorbed in the small intestine (AAT). The roughage DM intake in kilogram was specified as minimum and maximum requirements to be satisfied in the solution. The feed requirements (Table 2 in Asheim et al. 2014) were worked out for the Norwegian Red cattle breed and split between the indoor and pasture periods, depending on calving time and length of the seasons. The model allows for varying the feeding composition of silage, pasture and purchased concentrate mixtures, FF80 ${ }^{2}$ and FP45 indoors or FF80 and FE90 on pasture. The grazing period was assumed to be 115 days from June 6 to September 29. The variable costs and income of cereal crops were represented with data from the farm accounts. The analyses were conducted in the price level of 2013 and some of the prices and support premiums are reproduced in Table 1.

The average price of the milk was set to NOK 5.03/L (1 $€=$ NOK 7.81), and milk quality payments, due to somatic cells, bacterial count, odor, and taste, were assumed similar across production systems. The price is raised or lowered with NOK $0.07 / \mathrm{L}$ for each $0.1 \%$ change in the protein content of the milk from $3.2 \%$, and lowered by NOK $0.05 / \mathrm{L}$ for each $0.1 \%$ lowered fat content from $4.0 \%$. Farmers also received supplementary payments for milk delivered during the summer, NOK $0.32 / \mathrm{kg}$ for June and July, and NOK $0.50 / \mathrm{kg}$ for August and September, whereas NOK 0.19 was subtracted in the other months. The model assumed production of intermediate bull calves for slaughtering or to be finished as bulls elsewhere, and heifers for replacement or sale. Heifers were ready for calving at 22-25 months depending on feeding regime and were sold for NOK 35/kg live weight. The governmental premium payment per dairy cow was lowered if herd size was $>25$ cows and the premium per ha of farmland was lower for more than 20 ha (Table 1).

Intermediate calves obtained a price of NOK $48.46 / \mathrm{kg}$ plus NOK $10 / \mathrm{kg}$ in quality payments as such calf meat represents a

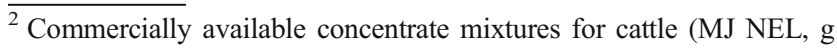
AAT/kg): F-Favør 80 (6.69, 107), F-Protein 45 (6.90, 230), and F-Elite $90(6.69,116)$.
}

niche or speciality production for the restaurant or institutional market. The slaughter weight needs to be $100-140 \mathrm{~kg}$ for intermediate calves. The intermediate calves obtained the grazing premium when born in the months from January until June, while those born in the other months obtained support on January 1. The feeding of the intermediate calves were specified with (i) no suckling, (ii) suckling for 3 days in the colostrum period, (iii) suckling for 7 weeks, and (iv) suckling for 13 weeks, all groups weaned at 13 weeks. The 13 weeks was chosen because this was the weaning age which $66.7 \%$ of the farmers reported in QB2.

The marginal work per animal was regarded to be constant to scale. The work per dairy cow was regarded to be the same whether the calf was suckling, or fed milk or milk replacer. Work on milking may be reduced due to less milk when suckling, but empty quarters may cause more work. Milking is anyway performed twice a day. The survey showed that most farmers $(73 \%)$ fed the calves milk 2-4 times a day (average 2.8 times). Feeding was conducted through a nipple from either a bucket or a bottle when the calf was young, with an increased use of bucket feeding as the calves grew older. The remaining calves suckled or used an automatic milk feeder. The surveyed farmers estimated average worktime to feed and care to $8.8 \mathrm{~min} /$ calf and day during the colostrum period, 7.7 min from then until 5 weeks and $6.1 \mathrm{~min}$ from 5 weeks until weaning, making $10.9 \mathrm{~h}$ in total until 13 weeks. Many farmers experience that suckling requires less work associated with calf feeding, although work to separate the calf before milking cannot be ruled out. While no or 3 days of suckling was assumed not to affect time spent with calf-associated work, 7 and 13 weeks of suckling was assumed to lower it by 5 and $10 \mathrm{~h}$, respectively, as compared to no or 3 days suckling.

The fixed costs for maintenance and depreciations of farm buildings as well as machinery depreciations, administration, and management etc. (NOK 421,391) were based on inflated numbers from the farm records. A fixed annual direct payment (NOK 122,000) to all milk producers in the country, as well as extra relief payments for the first eight dairy cows and a bottom subsidy deduction was taken into account. The farm milk quota was 174,511 L based on average of the farm accounts (NILF 2013a), and allows for about 25 dairy cows without suckling. Suckling may stimulate milk production so that milk deliveries per cow are not much affected; however, such cows would normally have a higher feed intake. In the model, suckling or intensive milk feeding was assumed to be followed by lower milk deliveries per cow and was compensated with more cows.

Farmers may experience that it is possible to keep cow and calf together in ordinary loose housing barns. This was also supported by Fröberg et al. (2011), Wagner et al. (2013), and Wagenaar and Langhout (2007). However, most new farm buildings are not designed for keeping cow and calves 
Table 1 Economic parameters, prices, and government farm payments

\begin{tabular}{|c|c|c|c|}
\hline Parameter & Value (NOK) & Parameter & Value (NOK) \\
\hline Receipts & & Livestock expenses $^{\mathrm{a}}$ & \\
\hline Milk price & $5.03 / \mathrm{L}^{\mathrm{b}}$ & F-Elite $90(6.69,116)^{\mathrm{c}}$ & $3.23 / \mathrm{kg}$ \\
\hline Meat price: & & F-Favør $80(6.69,107)^{\mathrm{c}}$ & $3.27 / \mathrm{kg}$ \\
\hline Cows & $37.22 / \mathrm{kg}$ & F-Calf conc. $(6.35,101)^{\mathrm{c}}$ & $3.40 / \mathrm{kg}$ \\
\hline Intermediate calves & $48.46 / \mathrm{kg}^{\mathrm{d}}$ & $\begin{array}{l}\text { F-Protein } 45(6.90,230)^{c} \\
\text { Other costs: }\end{array}$ & $4.89 / \mathrm{kg}$ \\
\hline Heifers, live weight & $35.00 / \mathrm{kg}$ & Cows ${ }^{\mathrm{e}}$ & $1695 / \mathrm{cow}$ \\
\hline Governmental payments & & Intermediate calves $^{\mathrm{e}}$ & $100 /$ calf \\
\hline Grassland, $1-20$ ha & 2810/ha & Heifers ${ }^{\mathrm{e}}$ & 1280/heifer \\
\hline Grassland, $>20$ ha & $2560 /$ ha & & \\
\hline Cereals, $<80$ ha & $3140 /$ ha & Other expenses & \\
\hline Dairy cows, $1-16$ & $4028 /$ cow & Fertilizer 22-2-12 & $3.64 / \mathrm{kg}$ \\
\hline Dairy cows, $16-25$ & $2072 /$ cow & Fertilizer 25-2-6 & $3.29 / \mathrm{kg}$ \\
\hline Dairy cows, $>25$ & $860 /$ cow & Fertilizer 18-3-15 & $3.85 / \mathrm{kg}$ \\
\hline Other cattle & $800 /$ head & $\operatorname{Lime}^{f}$ & $1500 /$ ton \\
\hline Relief payment, cows ${ }^{\mathrm{g}}$ & $2699 /$ cow & Diesel & $9.00 / \mathrm{L}$ \\
\hline Relief payment, other & 553/head & Seeds and herbicides & 2130/ha \\
\hline Cattle, grazing & 449/head & $\begin{array}{l}\text { Cost of labor } \\
\text { Fixed costs }\end{array}$ & $155 / \mathrm{h}$ \\
\hline Direct payment, milk prod. & $122,000 /$ year & Farm buildings etc. & 421,391/year \\
\hline
\end{tabular}

Source: NILF (2013b)

${ }^{a}$ Price for concentrate mixtures Felleskjøpet, 2013 (adding $10 \%$ for freight etc.)

${ }^{\mathrm{b}}$ The basic price is NOK 4.91 plus rural support 0.12

${ }^{\mathrm{c}}$ In parentheses: NEL in $\mathrm{MJ} / \mathrm{kg}$ and AAT in $\mathrm{g} / \mathrm{kg}$

${ }^{\mathrm{d}}$ In addition NOK $10 / \mathrm{kg}$ in quality calf payments from the slaughterhouse

${ }^{\mathrm{e}}$ Consist in costs of minerals and insemination and different items

${ }^{\mathrm{f}}$ Limestone is applied at a rate of 4 tons/ha in the meadow replacement year

${ }^{\mathrm{g}}$ In addition NOK 1276/cow for the first 8 cows, in total 10,208/year

together and e.g. slatted floors may represent a problem for the calves. In the survey the need to undertake investments to facilitate more suckling was mentioned by $15 \%$. Larger herds will require building investments, possibly including another calving pen, such extensions and remodeling were assumed to constitute NOK 68,100 per dairy cow based on Handbook of farm Management (NILF 2013b) and written down over 20 years at an interest rate of $3 \%$.

\section{Calf feeding and growth}

Calf feeding requirements until weaning in the four groups have been specified in Table 2. Milk intake by a suckling calf was assumed to correspond to $20 \%$ of its bodyweight in a day. Jasper and Weary (2002) showed that calves reared artificially and fed ad lib. drank $80 \%$ more (316 L vs $176 \mathrm{~L}$ ) than conventional ( $10 \%$ of bodyweight) fed calves, indicating a figure of ca $18 \%$ of the bodyweight. It is assumed that the milk intake of suckling calves will be even higher than that of calves fed artificially. Moreover, suckling stimulates milk production through oxytocin and cows with suckling calves may have a higher total milk production (Ryle and Orskov 1990; Krohn 2001). The $20 \%$ assessment assumed that the calf was suckling the dam; for calves suckling a foster cow the amount of milk (and growth rates) were generally lower (Nicoll 1982; Wyatt et al. 1977). The amount of suckled milk averaged $19.0 \mathrm{~L} \mathrm{milk/day} \mathrm{or} 1731 \mathrm{~L}$ in total for bull calves suckling 13 weeks (Table 2) while for calves suckling 7 weeks it constituted $13 \mathrm{~L} /$ day or $643 \mathrm{~L}$ in total. In the survey, milk yields (deliveries) per dairy cow were $6272 \mathrm{~L}$ for short suckling. For the long suckling group (suckling 5-6 weeks) in QB2 it was $4850 \mathrm{~L}$ i.e. $1422 \mathrm{~L}$ lower. This figure may, however, reflect other differences such as breed differences as some of the long suckling herds had less intensive breeds. De Passillé et al. (2008) found that Holstein calves allowed to suckle their dam twice daily drank $12 \mathrm{~L} /$ day. The amount of milk that the calf can suckle was assumed to be unaffected by milking since the daily milk yield is plenty relative to what the calf needs.

The model calculations assumed that calves were not fed any milk or milk replacer while suckling. Calves suckling for 3 days or 7 weeks were afterwards fed milk until weaning at 13 weeks. The amount of milk in this period was set to $10 \%$ of the bodyweight. For the 3-day suckling group, this gives expected values (bulls) of $7.0 \mathrm{~L} /$ day for the colostrum period and $5.9 \mathrm{~L} /$ day from colostrum to 5 weeks. The surveyed farmers estimated a calf on average would drink $5.7 \mathrm{~L}$ in the colostrum period and $6.4 \mathrm{~L}$ from then and until 5 weeks. The milk was 
Table 2 Assumptions for suckling and feeding up to 13 weeks (91 days) for intermediate calves and heifers according to suckling alternative

\begin{tabular}{|c|c|c|c|c|}
\hline & \multirow[t]{2}{*}{ No suckling } & \multicolumn{3}{|c|}{ Length of the suckling period } \\
\hline & & 3 days & 7 weeks & 13 weeks \\
\hline \multicolumn{5}{|c|}{ Intermediate calves (birthweight $=42 \mathrm{~kg}$ ) } \\
\hline Fresh milk suckled in total, $\mathrm{L}$ & 0 & 26 & 643 & 1731 \\
\hline Fresh milk feeding in total, $\mathrm{L}$ & 323 & 677 & 456 & 0 \\
\hline Milk replacer, kg powder & 45 & 0 & 0 & 0 \\
\hline Concentrates, FEm ${ }^{\mathrm{a}}$ & 71 & 71 & 71 & 71 \\
\hline Hay, FEm ${ }^{\mathrm{a}}$ & 22 & 22 & 22 & 22 \\
\hline Silage, FEm ${ }^{\mathrm{a}}$ & 7 & 7 & 7 & 7 \\
\hline ADG until week $13, \mathrm{~kg}$ live & 0.63 & 0.74 & 0.95 & 1.16 \\
\hline Liveweight at 13 weeks & 99 & 109 & 128 & 147 \\
\hline \multicolumn{5}{|l|}{ Heifers (birthweight = 38 kg) } \\
\hline Fresh milk suckled in total, $\mathrm{L}$ & 0 & 24 & 582 & 1566 \\
\hline Fresh milk feeding in total, $\mathrm{L}$ & 292 & 612 & 413 & 0 \\
\hline Milk replacer, kg powder & 40 & 0 & 0 & 0 \\
\hline Concentrates, FEm ${ }^{\mathrm{a}}$ & 66 & 66 & 66 & 66 \\
\hline Hay, FEm ${ }^{\mathrm{a}}$ & 25 & 25 & 25 & 25 \\
\hline Silage, FEm ${ }^{\mathrm{a}}$ & 11 & 11 & 11 & 11 \\
\hline ADG until week $13, \mathrm{~kg}$ live & 0.57 & 0.67 & 0.86 & 1.05 \\
\hline Liveweight at 13 weeks & 90 & 99 & 116 & 133 \\
\hline
\end{tabular}

${ }^{\mathrm{a}} 1 \mathrm{FEm}$ approximates to 6.9 megajoule (MJ) or the net energy in $1 \mathrm{~kg}$ of barley

most often $(56 \%)$ given fresh. Acidified milk was provided by $30 \%$, and the daily milk intakes estimated were lower, on average 4.1 , and $6.1 \mathrm{~L} /$ calf in the two periods. Our assumption of milk and milk replacer restricted to $10 \%$ of the calf live weight corresponds reasonably well to the survey. For the no suckling group, it was assumed calves were fed similar amounts, i.e. $5 \%$ of body weight with milk replacer and $5 \%$ milk. Based on Hansen et al. (2011) it was assumed $138 \mathrm{~g}$ of milk replacer powder "Kalvegodt"/L which provide energy levels corresponding to that of whole milk.

The use of roughage and concentrates until 13 weeks is probably somewhat lower for the long suckling calves, but was nevertheless assumed equal in all groups and not affected by how suckling was organized. The feedings in this period (Table 2) were set to 22-25 FEm of hay, 7-11 FEm of silage, and 66-71 FEm of concentrates/calf based on Hansen et al. (2011); Table 5.1 for heifer and Table 5.3 for bull calves. In general, fine hay is recommended for young calves, however it can be expensive compared to silage. Of the surveyed farmers, $36 \%$ used hay for the calves during the colostrum period, $67 \%$ up to 5 weeks, and $57 \%$ from then until weaning while 16,70 , and $94 \%$ used silage and 38, 91, and $94 \%$ gave concentrates in the three periods, respectively. The amounts of silage and concentrates were gradually increased as the calves became older. In general, the daily amounts indicated in the survey were higher than in Hansen et al. (2011), particularly for hay and silage.
Average daily growth rates (ADG) were set to $0.6 \mathrm{~kg}$ live weight (no suckling), $0.7 \mathrm{~kg}$ ( 3 days suckling), $0.9 \mathrm{~kg}$ (suckling during 7 weeks), and $1.1 \mathrm{~kg}$ (long suckling). The rates were $10 \%$ higher for bull than heifer calves (Table 2). The rate for the no suckling alternative was somewhat higher than Jasper and Weary (2002) who reported that daily growth up to weaning at day 36 was $0.48 \mathrm{~kg}$ /day for conventional restricted milk feeding ( $10 \%$ of body weight) versus $0.78 \mathrm{~kg}$ for ad lib. milk feeding for Holstein heifer calves (the ad lib. group grew best pre-weaning; however the conventional had the highest growth rate during weaning and after). For 3 days suckling, the slaughter weights in the NDHRS database increased by $0.42 \mathrm{~kg} /$ day for bull calves and bulls, and by $0.32 \mathrm{~kg}$ /day for heifer calves up to 1.5 year. This corresponded quite well with our chosen rate $(0.7 \mathrm{~kg})$, assuming a dressing percentage of 50 . As for the 7 weeks suckling alternative, they were based on findings in a study of 6 weeks suckling (Johnsen et al. 2015a). The rates for long suckling were based on own judgment and on Grøndahl et al. (2007), representing a well-managed dairy farm with Norwegian Red Cattle practicing suckling over many years.

After weaning, the calves born in October were finished on a ration of roughage and concentrate or pasture and concentrate when the calving took place in May. In this period, a weight gain of $1.0 \mathrm{~kg} /$ day for all alternatives was assumed. The time to finish the intermediate calves depended on weight at weaning. The carcasses were assumed to be of equal quality. 


\section{Health and animal welfare}

The model assumptions regarding effects of suckling on health and welfare of calves and cows were based on the surveys coupled with the NCHRS database, and summarized in Table 3. The following calf disease groups were recorded: respiratory disorders, infectious diarrhea, gastroenteritis, parasitic diseases, lice, infectious arthritis, and abscesses. In total, the number of treated cases per one hundred cows was 1.7 in the long suckling group, 18.5 for the short suckling group, and 32.5 in the no suckling group thus clearly indicating an increased risk of more calf diseases due to limited suckling. A low occurrence of calf diseases following a long suckling period was also supported by Grøndahl et al. (2007) and by Weary and Chua (2000). The costs of the calf diseases were assessed by assuming NOK 1300/treatment. A regular 20-min visit by a cattle veterinarian would typically cost NOK 660 in. e.g. Hallingdal (http://www.hallingvet.no/index.php/storfe/) plus travel and medicine, medicine reporting, and other costs.

Gulliksen et al. (2009) give an average figure of $3.6 \%$ calf mortality in Norwegian dairy herds in the NHDRS and this figure has been used for all suckling groups of intermediate calves as we were unable to come up with any significant differences in the data material. The figure excluded abortions and stillbirths and was roughly in line with that of other European countries (Gulliksen et al. 2009). As for heifers, both mortality and disease risks would be higher since they cover a longer period. The difference was assumed to constitute $5 \%$ increased risk compared to intermediate calves.

In general, the cow health figures reflected those of calves and were most favorable for the long suckling group. The way the study was carried out, the effects for the cows reflect both short and long term effects. The number of cows treated for a disease was 32/100 for the long suckling group versus 46 for the short suckling and 68 for the no suckling groups. The difference between the long and no suckling groups was approaching significance $(p<0.06)$. For mastitis the figures were 6 cows (long suckling), 9 cows (short suckling) and 16 cows (no suckling) treated/100 cows. Teat trampling, ketosis, metritis, ovarian cysts, and retained placenta, occurred in small numbers in all groups, however the tendency was slightly higher frequencies in the no or short suckling groups compared to long suckling. None of these differences were significant. For paresis puerperalis (milk fever) and indigestion no differences could be detected. Treatment for lack of heat is not permitted in organic dairy farming and no cases were reported. However, an index of reproduction diseases (FS tall) showed 4 cases/100 cows in the short and no suckling groups versus only 1 in the long suckling group. The way the grouping of the material was conducted, any effect on reproduction might be due to the fact that cows were nursing calves, or had a history of suckling as calves, or a combination of the two.
Table 3 Mortality and disease risks for intermediate calves and heifers and disease risks and other effects on cows or milk according to suckling alternative

No suckling Length of the suckling period

3 days 7 weeks 13 weeks

Effects on intermediate calves

Disease incidence, $\% \quad 33$

Mortality rate, $\% \quad 3.6$

19

$\begin{array}{lll}9 & 2 & 2\end{array}$

Effects on heifers

Disease incidence, $\% \quad 35$

Mortality rate, $\% \quad 3.8$

$\begin{array}{lll}3.6 & 3.6 & 3.6\end{array}$

Effects on cows

Disease incidence, $\% \quad 68$

Mastitis incidence, \% 16

Replacement rate, $\% \quad 38$

Calving interval, months 12.0

Effects on milk

$\begin{array}{lllll}\text { Yield in first lactation } & 0 & 0 & +200 \mathrm{~L} & +200 \mathrm{~L} \\ \text { Protein content } & 0 & 0 & 0 & +0.2 \mathrm{pp} \\ \text { Cell count } & 0 & 0 & 0 & 0\end{array}$

Source: Mortality rates: Gulliksen et al. (2009), milk protein: Lidfors and Johansen (2006), and other effects: the questionnaires

The costs of mastitis in Norwegian dairy herds have been estimated to NOK 160 million for 35,360 reported treatments in 2013 (Tine Rådgiving 2014). This gives an average cost of NOK 4525/case which has been used in the model. An important reason for the high figure was withholding of milk from mastitis treated cows. Other cow diseases were assumed to cost less than mastitis and have been estimated to NOK 2000 based on data from Hallingdal (http://www.hallingvet. no/index.php/storfe/), including medicine and production losses. Another consequence of diseases follows culling and associated costs on replacements. However, different replacement rates may also reflect different replacement strategies among the groups, Gröhn et al. (2003) and Heikkilä et al. (2008) have indicated lower rates for involuntary culling than typically are indicated for replacement. Average annual replacement was 38 and 37 cows/100 breeding cows in the no and short suckling group respectively, versus 29 in the long suckling group, while the number of cows recruited was 41,40 , and 32 in the three groups, respectively. The replacement rates and calving intervals in the model (Table 3) were assessed based on the survey.

Age at first calving was assumed to be similar for all heifers, 24 months. Farmers will try to adjust the time for the first insemination in accordance with desired calving season in addition to the age and weight of the heifer. The calving intervals were slightly longer for herds practicing long suckling (384 days) as compared to short (378 days) and no suckling (368 days). Milk production was assumed to be 200 
$400 \mathrm{~L}$ higher in the first lactation for heifers that have received high levels of milk as calf since these heifers will have a higher weight when calving (Table 3). In the survey, somatic cell count numbers were slightly higher, $148,000 / \mathrm{ml}$ for long suckling versus 130,000 for short or no suckling. The milk somatic cell count numbers were assumed to be unaffected by suckling since the figures were all below the threshold corresponding to high-quality milk "Elite milk". It was assumed that the protein content of the milk would be 0.2 ppts higher in the longest suckling group. Unfortunately, there were not many studies of long-term effects of suckling and the assumption on increased protein content was based on Lidfors and Johansson (2006) who found a significant difference. The change in milk fat content due to suckling can result in a substantial reduction in the milk price but since it was only for the milk delivered during the suckling period it was treated exogenously in the LP model.

The model was specified in Excel and solved by the standard solver (Frontline Systems Inc.). The model calculations were undertaken assuming seasonal calving in the middle of October and alternatively in the middle of May. We also undertook calculations with $30 \%$ higher beef prices assuming milk prices were unchanged. This will change the economics of producing beef using more milk and was conducted for the October calving alternative.

\section{Results}

The results (Tables 4 and 5) showed that on Norwegian dairybeef farms, farm profit increased as the suckling period was increased from 3 days to 7 weeks when there were resources like farmland available for having more cows. A combination of better growth, lower incidence of sick cows and calves seem to compensate for investments and the increased number of cows needed to produce the quota. Moreover, there seems to be a limit regarding how long the calf should suckle the dam, extended suckling up to 13 weeks seemed questionable as the calf will drink a lot of milk in such a long period.

In general, May calving was profitable since cheap pasture feed can replace some concentrates. There are currently seasonal increments in the milk price from June so that the milk consumed by the calf will have a higher alternative value. However, moving the time of calving from mid-October to the middle of May does not alter these results much as the ranging of the alternatives remains unchanged (Table 5).

The 13 weeks suckling alternative was slightly less competitive given calving in May due to the higher price of the milk in summer while the 3-day suckling alternative was about as competitive as with calving in October.

Clearly, a lower milk fat content will affect the outcome of the calculations and a decrease of $1 \%$ in milk fat content would make the suckling alternatives less profitable than the 3-day suckling alternative (data not shown). A final model run was conducted using $30 \%$ higher prices for beef in the October calving alternative (data not shown). Such a price increase would raise farm profit considerably for all alternatives, however the optimal solution did not change with these price changes and the 7 weeks suckling alternative remained better than the others with a calculated farm profit per hour of NOK 194. However, in such a situation it would be better to allow cow-calf suckling for 13 weeks compared to no suckling or suckling for 3 days as the higher beef price would justify more milk to the calves.

\section{Discussion}

Separation of cow and calf right after birth followed by restricted milk feeding is a mainstream strategy for raising calves on conventional dual purpose dairy-beef farms in Norway (Hansen et al. 2011). After a minimum suckling period required in organic dairy farming, the amounts of milk given to calves, as suggested by the surveyed farmers, with a few exceptions indicate that restricted milk feeding also was customary in organic dairy-beef production systems. In contrast to the common management regime, the model results presented here showed that suckling up to a certain level (7 weeks) may have a positive influence upon the farm economics. The effect was due to the assumed positive influence on calf growth and on health and welfare for both calves and cows. Moreover, when facing a milk quota situation, dual purpose dairy and beef farms may find it profitable to shift to more suckling and more cows in order to have more calves for beef. The changeover to more suckling does not make a huge economic difference, but should likely be sufficient to make it worthwhile in many cases. The positive effects are likely to be encountered both in a short and a long run.

Different economic aspects of effects of suckling have been considered in the study, some of them more obvious than others. For instance, research clearly indicates that heifer calves fed high amounts of milk also have higher milk yield in their first lactation (Shamay et al. 2005). This follows better growth and a higher weight at calving. Alternatively, such animals can be mated or slaughtered at a lower age. Other model assumptions such as the health effects of extended suckling on cows and calves were more uncertain as the long suckling herds were few and considerably smaller than the average of the other farms. The low disease incidence found in these herds may be due to other causes such as a low total milk yield, or more animal welfare conscious farmers, and may have biased the model outcome. On the other hand, negative effects of early separation of cows and calves (maternal deprivation) on animal welfare is a concern, and we cannot rule out any connection between increased diseases and higher treatment costs and production losses in such production 
Table 4 Basic model solutions for a dairy-beef farm assuming calving in October and no suckling compared to suckling for 3 days, 7 weeks and 13 weeks

\begin{tabular}{|c|c|c|c|c|}
\hline & \multirow[t]{2}{*}{ No suckling } & \multicolumn{3}{|c|}{ Length of the suckling period } \\
\hline & & 3 days & 7 weeks & 13 weeks \\
\hline \multicolumn{5}{|l|}{ Land use and livestock } \\
\hline Silage, hay, pasture and renewal, ha & 23.0 & 24.2 & 25.5 & 26.6 \\
\hline Permanent pasture (enclosed), ha & 10.2 & 10.8 & 9.6 & 7.4 \\
\hline Barley, ha & 2.5 & 0.6 & 0 & 0 \\
\hline Total area, ha & 40.3 & 40.3 & 40.3 & 40.3 \\
\hline Dairy cows, heads & 24.6 & 25.9 & 27.4 & 30.2 \\
\hline \multicolumn{5}{|l|}{ Financial results (NOK) } \\
\hline Gross output from farming & $1,392,740$ & $1,464,897$ & $1,551,861$ & $1,697,901$ \\
\hline Government area payments & 104,326 & 108,229 & 109,333 & 109,333 \\
\hline Other payments & 230,291 & 242,317 & 256,212 & 282,070 \\
\hline \multicolumn{5}{|l|}{ Variable costs, including } \\
\hline Forages and grain & 282,810 & 310,004 & 323,570 & 330,467 \\
\hline Concentrates & 179,977 & 177,725 & 188,352 & 227,124 \\
\hline Miscellaneous, livestock & 146,691 & 163,096 & 206,462 & 320,707 \\
\hline Gross margin & 783,262 & 814,071 & 833,476 & 819,601 \\
\hline Hired work costs & 117,790 & 123,408 & 129,899 & 141,979 \\
\hline Fixed costs & 292,183 & 296,416 & 303,220 & 315,884 \\
\hline Farm profit & 373,289 & 394,247 & 400,357 & 361,738 \\
\hline Farm profit per hour & 148 & 154 & 163 & 153 \\
\hline
\end{tabular}

Source: LP model calculations

systems. If calf mortality rates are lowered due to suckling giving a better nutritional state of suckling calves, this will add to the advantages. We did not take into account possible differences in calf mortality between the suckling groups as that could not be detected in the material. More long-term studies are clearly needed to confirm or reject these results.

The young calf in particular is vulnerable to inadequate treatment and more so the younger it is. Suckling restricted to the colostrum period, and followed by milk feeding until 13 weeks, had only a slight positive influence on the farm economics compared to no suckling at all. Still it might be more advantageous than captured by the model since the assumed positive effect of a short suckling period and more whole milk feeding has been regarded to be sufficient relative to the work and stress (Enríquez et al. 2011; Weary et al. 2008) following breaking the bonds. With an increasing length of the

Table 5 Model solutions for a dairy-beef farm assuming calving in May and no suckling compared to suckling for 3 days, 7 weeks, and 13 weeks

\begin{tabular}{|c|c|c|c|c|}
\hline & \multirow{2}{*}{$\begin{array}{l}\text { No } \\
\text { suckling }\end{array}$} & \multicolumn{3}{|c|}{ Length of the suckling period } \\
\hline & & 3 days & 7 weeks & 13 weeks \\
\hline \multicolumn{5}{|l|}{ Land use and livestock } \\
\hline Silage, hay, pasture and renewal, ha & 23.1 & 24.3 & 24.9 & 24.2 \\
\hline Permanent pasture (enclosed), ha & 10.0 & 10.5 & 10.1 & 9.7 \\
\hline Barley, ha & 2.6 & 0.6 & 0 & 0 \\
\hline Pasture mountain area, ha & 40.3 & 40.3 & 40.3 & 40.3 \\
\hline Dairy cows, heads & 24.6 & 25.9 & 27.4 & 30.2 \\
\hline \multicolumn{5}{|l|}{ Financial results (NOK) } \\
\hline Gross output from farming & $1,426,108$ & $1,499,258$ & $1,588,253$ & $1,736,930$ \\
\hline Government area payments & 104,191 & 108,086 & 109,333 & 109,333 \\
\hline Other payments & 230,291 & 242,317 & 256,212 & 282,070 \\
\hline \multicolumn{5}{|l|}{ Variable costs, including } \\
\hline Forages and grain & 282,622 & 309,806 & 319,753 & 316,063 \\
\hline Concentrates & 171,314 & 168,443 & 183,351 & 233,155 \\
\hline Miscellaneous, livestock & 147,974 & 166,932 & 213,248 & 332,982 \\
\hline Gross margin & 824,198 & 854,077 & 871,902 & 854,729 \\
\hline Hired work costs & 117,790 & 123,408 & 129,899 & 141,979 \\
\hline Fixed costs & 292,183 & 296,416 & 303,220 & 315,884 \\
\hline Farm profit & 414,225 & 434,252 & 438,782 & 396,866 \\
\hline Farm profit per hour & 165 & 170 & 179 & 169 \\
\hline
\end{tabular}

Source: LP model calculations 
suckling period, the benefits for calf welfare may outweigh some of the stress experienced during the separation. An ethical question to be raised is also whether the stress the animals experience at separation, justifies a few days of suckling. The behavioral reactions to separation will last for 3 (2-4) days (Johnsen et al. 2015b), and will be stronger but not lasting longer as the suckling period is extended (Fröberg and Lidfors 2009). Natural weaning takes place as late as 89 months in a gradual process, and is hardly an option in dual dairy-beef production systems. In cattle, the mother-young bond is formed within hours after birth, so using a calving pen or allowing birth to take place on pasture will inevitably result in bonding taking place. If cow and calf have been together for some hours in the first place, it may be favorable to keep them together for longer. In a review article, Krohn (2001) concluded that even a few days together was beneficial for the calf, while Flower and Weary (2003) argued that separation was likely to have some welfare effects regardless of when it occurs. A study comparing effects on heart rates in cows following separation on day 1,4 , and 7 Stěhulová et al. ( 2008) reported increased heart rate in all cows immediately after separation. But it was not influenced by the calf's age or by the cows' contact with the calf.

An important economic question is also how much milk the suckling calf will drink in a day. In this study, it was assumed that the milk intake corresponds to $20 \%$ of the calves' weight. The question is not easily investigated as suckling calves may drink more than calves reared artificially and fed milk ad libitum. The percentage may become lower as the calves grow bigger and that may favor longer suckling making the 13 weeks alternative more competitive. Long suckling has been associated with lower milk deliveries which were also found in this study. However, several studies have reported that gained milk over the entire lactation may be unaffected for high-yielding cows nursing their calves (Johnsen et al. 2015a; Metz 1987; Kišac et al. 2011).

Calf growth rates pre-weaning are closely related to milk feeding intensity. The daily calf growth rate (Table 2) was assumed to increase from 0.6 to $0.7 \mathrm{~kg}$ as the amount of milk was increased slightly and replaced the milk replacer in the 3 days suckling alternative compared to no suckling. For suckling in 7 weeks the rates were increased to $0.9 \mathrm{~kg} / \mathrm{day}$, and for suckling in 13 weeks they reached $1.1 \mathrm{~kg} /$ day. Due to a positive effect on calf health (i.e., fewer calf diseases) and welfare (e.g. allowing maternal care, possibility to suckle when hungry) in combination with lower costs related to loss of saleable milk as compared to the 13 weeks suckling alternative, the results favor suckling for 7 weeks. Nevertheless, it is important to stimulate the intake of enough solid feed before weaning, otherwise the transition will be difficult for the calf and result in a dip in growth. However, calves younger than 3 weeks are not able to compensate for low milk allowance by eating more solid feed (Sweeney et al. 2010).
Another uncertain assumption deals with effects of suckling on milk quality. Studies have shown no or a slight negative effect of suckling on milk somatic cell count in herds with a previous low cell count (Jago et al. 2010; Edwards et al. 2013), but it has been assumed the effect is too small to be taken into account. Based on just one study (Lidfors and Johansson 2006) we assumed the milk protein content may be higher resulting in a better milk price with very long suckling (13 weeks). However, in spite of the increased milk protein content, the results do not support suckling for 13 weeks. Nevertheless, even with a very cautious interpretation of the results, and taking uncertainty into consideration, suckling for some weeks may be an economically viable option for calf rearing. An effect of suckling that may alter this conclusion is the effect of suckling on the milk fat content. Milk price deduction can be substantial if the milk fat content is lowered by one percentage point and, although it will only affect the milk delivered during the suckling period, it could still be felt on the longer suckling alternatives. The effect could possibly be mitigated by the way suckling is carried out, and by, e.g. using foster cows that are not milked, it can be avoided.

About one in five of the surveyed farmers (19\%) combined suckling and milking in the indoor period, and $23 \%$ in the grazing period. Another $4 \%(9 \%$ in the grazing period) assumed it might work on their farm though they did not practice it. Keeping cow and calf together during the colostrum period varied with season, as more than $90 \%$ of the respondents practiced it during the grazing period but only $73 \%$ during the indoor season. As for the indoor period, the main reasons against practicing suckling were more dairy cows to fill the quota (25\%), more work (19\%), and other reasons $(18 \%)$. The main other reasons were different stress and uneasiness problems, problems related to the suitability of the cow house, and practicality of the current arrangement. Only $3 \%$ reported lack of grazing area for more cows. More work on the practical arrangements of suckling on dual purpose dairy-beef farms, such as more gradual weaning or suckling only during daytime, should be encouraged in further work.

The price of the beef relative to that of milk influences the economics of suckling and milk feeding to calves. However, if suckling for 13 weeks should be economically viable in dairybeef farming systems the beef price has to be raised substantially. A transfer to later slaughtering of male animals as bulls or steers rather than the intermediate calves is a more likely effect of raising beef prices. Such alternatives were not investigated in this study. The milk quota system as such also favors suckling as it is a limit on milk production. Surplus milk has a low alternative value on the market and may be used to increase beef production. Abolishing the milk quota system may, on the other hand, lead to lower milk prices so a final outcome on suckling by such a policy change is by no way given. 
Finally, consumers may choose to vote with their wallets by refusing to buy certain products produced in ways that they do not approve, or citizens who oppose certain practices can provide their political support to new regulations (von Keyserlingk et al. 2013). Suckling systems may become more profitable if consumers, due to animal welfare concerns, are willing to pay more for milk from such production systems or for meat from calves that have experienced long suckling. Some kind of regulation might also be implemented to enforce the practice if desired by the public.

\section{Conclusion}

There may be both practical and economic limits for how long calves should be suckling on Norwegian dual purpose milk and beef farms, and investments may be needed to facilitate more suckling. Nevertheless, under the conditions used in the study, production systems allowing for longer suckling than currently common were profitable due to effects on the overall production economics, through weight gain of the calves as well as improved animal welfare and health of cows and calves. Even with a very cautious interpretation of results, and taking uncertainty into consideration, suckling for some weeks may be an economically viable option for calf rearing on such farms. Farmers should, however, pay attention to the fat content of the milk delivered during the suckling period, as the deduction in the milk price due to lower fat content can be substantial. More work on the practical arrangements of suckling should be encouraged in further studies.

Acknowledgments We acknowledge with appreciation the funding of the study from the Foundation for Research Levy on Agricultural Products (FFL), the Agricultural Agreement Research Fund (JA) and the Research Council of Norway (Norwegian Research Council project number 190424). We are grateful for the two anonymous reviewers who helped us improve the article considerably.

Open Access This article is distributed under the terms of the Creative Commons Attribution 4.0 International License (http:// creativecommons.org/licenses/by/4.0/), which permits unrestricted use, distribution, and reproduction in any medium, provided you give appropriate credit to the original author(s) and the source, provide a link to the Creative Commons license, and indicate if changes were made.

\section{References}

Asheim LJ, Lunnan T, Sickel H (2014) The profitability of seasonal mountain dairy farming in Norway. Ger J Agric Econ 63(2):81-95

Bar-Peled U, Robinzon B, Maltz E, Tagari H, Folman Y, Bruckental I, Voet H, Gacitua H, Lehrer AR (1997) Increased weight gain and effects on production parameters of Holstein heifer calves that were allowed to suckle from birth to 6 weeks of age. J Dairy Sci 80(10): $2523-2528$
Boogaard BK, Oosting SJ, Bock BB (2008) Defining sustainability as a socio-cultural concept: citizen panels visiting dairy farms in the Netherlands. Livest Sci 117(1):24-33

Carruthers TD, Hafs HD (1980) Suckling and four-times daily milking: influence on ovulation, estrus and serum luteinizing hormone, glucocorticoids and prolactin in postpartum Holsteins. J Anim Sci 50(5):919-925

Combellas J, Tesorero M (2003) Cow-calf relationship during milking and its effect on milk yield and calf live weight gain. Livest Res Rural Dev 15(3) paper 24

de Passillé AM, Marnet P-G, Lapierre H, Rushen J (2008) Effects of twice-daily nursing on milk ejection and milk yield during nursing and milking in dairy cows. J Dairy Sci 91(4):1416-1422

Det kongelige landbruksdepartement (2002) Stortingsmelding $n r .12$ (2002-2003) Om dyrehold og dyrevelferd, (Ministry of Agriculture, White paper no 12, Animal husbandry and animal welfare, in Norwegian), Oslo, URL: https://www.stortinget.no/nn/Saker-ogpublikasjonar/Stortingsforhandlingar/Lesevisning/?p=20022003\&paid=3\&wid=b\&psid=DIVL640\&pgid=b_0377, $182 \mathrm{p}$

Edwards JP, Jago JG, Lopez-Villalobos N (2013) Milking efficiency for grazing dairy cows can be improved by increasing automatic cluster remover thresholds without applying premilking stimulation. J Dairy Sci 96(6):3766-3773

Ellingsen K, Johnsen JF, Schjøll A, Grøndahl AM, Mejdell CM (2015) Kalvestell blant produsenter av økologisk melk $i$ Norge og Sverige, Resultater fra en spørreundersøkelse, Kalvestell $i$ norsk og svensk økomelkproduksjon (Nursing of calves in Norwegian and Swedish organic dairy production, Results from a survey, in Norwegian, Norwegian Veterinary Institute's Report Series) Veterinærinstituttets rapportserie 16-2015, Oslo, Veterinærinstituttet, $65 \mathrm{p}$

Enríquez D, Hötzel MJ, Ungerfeld R (2011) Minimising the stress of weaning of beef calves: a review. Acta Vet Scand 53:28, 8 p

Flower F, Weary DM (2003) The effects of early separation on the dairy cow and calf. Anim Welf 12(3):339-348

FOR (2005) Forskrift om økologisk produksjon og merking av økologiske landbruks-produkter og noeringsmidler, (Regulation on organic production and labelling of organic agricultural products and foodstuffs, in Norwegian), URL: https://lovdata.no/dokument/SF/forskrift/ 2005-10-04-1103

Fröberg S, Lidfors L (2009) Behaviour of dairy calves suckling the dam in a barn with automatic milking or being fed milk substitute from an automatic feeder in a group pen. Appl Anim Behav Sci 117(3-4): $150-158$

Fröberg S, Lidfors L, Svennersten-Sjaunja K, Olsson I (2011) Performance of free suckling dairy calves in an automatic milking system and their behaviour at weaning. Acta Agric Scand Sect A Anim Sci 61(3): 145-156

Gröhn YT, Rajala-Schultz PJ, Allore HG, DeLorenzo MA, Hertl JA, Galligan DT (2003) Optimizing replacement of dairy cows: modeling the effects of diseases. Prev Vet Med 61(1):27-43

Grøndahl AM, Skancke EM, Mejdell CM, Jansen JH (2007) Growth rate, health and welfare in a dairy herd with natural suckling until 6-8 weeks of age: a case report. Acta Vet Scand 49(16)

Gulliksen SM, Lie KI, Løken T, Østerås O (2009) Calf mortality in Norwegian dairy herds. J Dairy Sci 92(6):2782-2795

Hansen HS, Havrevoll Ø, Berg J, Bævre L, Nyhus LT, Gulliksen SM (2011) Melkefôring av kalv. Utredning basert på tidgjengelig litteratur og praktiske erfaringer, Utredning nr. 127, (Milk feeding of calves, Report no 127, in Norwegian) Høgskolen i NordTrøndelag, Steinkjer, $42 \mathrm{p}$

Heikkilä A-M, Nousiainen JI, Jauhiainen L (2008) Optimal replacement policy and economic value of dairy cows with diverse health status and production capacity. J Dairy Sci 91(6):2342-2352

Jago JG, Burke JL, Williamson JH (2010) Effect of automatic cluster remover settings on production, udder health, and milking duration. J Dairy Sci 93(6):2541-2549 
Jasper J, Weary DM (2002) Effects of ad libitum milk intake on dairy calves. J Dairy Sci 85(11):3054-3058

Johnsen JF, Beaver A, Mejdell CM, Rushen J, de Passillé AM, Weary D (2015a) Providing supplementary milk to suckling dairy calves improves performance at separation and weaning. J Dairy Sci 98(7): $4800-4810$

Johnsen JF, Ellingsen K, Grøndahl AM, Bøe KE, Lidfors L, Mejdell CM (2015b) The effect of physical contact between dairy cows and calves during separation on their post-separation behavioural response. Appl Anim Behav Sci 166:11-19

Khan MA, Weary DM, von Keyserlingk MAG (2011) Invited review: effects of milk ration on solid feed intake, weaning, and performance in dairy heifers. J Dairy Sci 94(3):1071-1081

Kišac P, Brouček J, Uhrinčat' M, Hanus A (2011) Effect of weaning calves from mother at different ages on their growth and milk yield of mothers. Czech J Anim Sci 56(6):261-268

Krohn CC (2001) Effects of different suckling systems on milk production, udder health, reproduction, calf growth and some behavioural aspects in high producing dairy cows - a review. Appl Anim Behav Sci 72(3):271-280

Krohn CC, Jonasen B, Munksgaard L (1990) Cow-calf relations, 3, The effect of 6-8 weeks suckling on behaviour of the cow, milk production and udder health and reproduction, (Statens Husdyrsbrugsforsøg, Meddelelse 773, 1-4, in Danish), Denmark

Langhout J, Wagenaar JPTM (2006) Suckling, a natural calf rearing system in organic dairy farms, Joint organic congress, Theme 7: Development of livestock production system, URL: http://www. louisbolk.org/downloads/1767.pdf, Denmark, May 30-31, 2 p

Lidfors L, Johansson B (2006) Olika system för uppfödning av kalvar Delprojekt 3. Långtidseffekter av att låta kvigkalvar dia en amko eller få olika mängd mjölk, Slutrapport till Stiftelsen Lantbruksforskning, (Different systems for the rearing of calves Subproject 3. Long-term effects of allowing the heifer calves suckle a cow or get different amounts of milk, Final report to the Foundation for Agricultural Research, in Swedish), Institutionen för husdjurens miljö och hälsa, Sveriges lantbruksuniversitet, Skara, Sverige

Metz J (1987) Productivity aspects of keeping dairy cow and calf together in the post-partum period. Livest Prod Sci 16(4):385-394

Moallem U, Werner D, Lehrer H, Zachut M, Livshitz L, Yakoby S, Shamay A (2010) Long-term effects of ad libitum whole milk prior to weaning and prepubertal protein supplementation on skeletal growth rate and first-lactation milk production. J Dairy Sci 93(6): 2639-2650

Moss RJ, O'Grady P (1978) Effect of multiple suckling on liveweight, milk production and fertility of dairy cows, in: Proceedings of the Australian Society on Animal Production, 12, 224 (abstract)

Nicoll GB (1982) Effects of double suckling at pasture. 2. Calf performance. Anim Prod 35(3):395-400

NILF (Norsk institutt for landbruksøkonomisk forskning) (2013a) Driftsgranskingar i jord- og skogbruk, Rekneskapsresultat 2012, (Account results in agriculture and forestry 2012, Annual publication, $\mathrm{n}^{\circ} \mathrm{S}-102-13$, in Norwegian), Norwegian Agricultural Economics Research Institute, Oslo, $239 \mathrm{p}$

NILF (Norsk institutt for landbruksøkonomisk forskning) (2013b) Handbok for driftsplanlegging 2013/2014, (Handbook of farm planning 2013/2014, Annual publication, ISBN 978-82-7077-868-3, in Norwegian), Norwegian Agricultural Economics Research Institute, Oslo

Piccinali RL, Monje AR (2000) Sexual activity in early weaned cows. Vet Argent 17(164):257-261

Ryle M, Orskov ER (1990) On milk yields and calf rearing. Livest Res Rural Dev 2(3)

Shamay A, Werner D, Moallem U, Barash H, Bruckental I (2005) Effect of nursing management and skeletal size at weaning on puberty, skeletal growth rate, and milk production during first lactation of dairy heifers. J Dairy Sci 88(4):1460-1469

Soberon F, Raffrenato E, Everett RW, Van Amburgh ME (2012) Preweaning milk replacer intake and effects on long-term productivity of dairy calves. J Dairy Sci 95(2):783-793

Stagg K, Spicer LJ, Sreenan JM, Roche JF, Diskin MG (1998) Effect of calf isolation on follicular wave dynamics, gonadotropin and metabolic hormone changes, and interval to first ovulation in beef cows fed either of two energy levels postpartum. Biol Reprod 59(4):777783

Stěhulová I, Lidfors L, Špinkaa M (2008) Response of dairy cows and calves to early separation: effect of calf age and visual and auditory contact after separation. Appl Anim Behav Sci 110(1-2):144-165

Sweeney BC, Rushen J, Weary DM, de Passillé AM (2010) Duration of weaning, starter intake, and weight gain of dairy calves fed large amounts of milk. J Dairy Sci 93(1):148-152

Terré M, Tejero C, Bach A (2009) Long-term effects on heifer performance of an enhanced-growth feeding programme applied during the preweaning period. J Dairy Res 76(3):331-339

The Norwegian Council for Animal Ethics (1997) Skille av melkeku og kalv etter fødselen. Uttalelse fra rådet for dyreetikk avgitt $i$ juni 1997, (Partition of dairy cattle and calf after birth. Statement made in June 1997, in Norwegian), URL: http://www.radetfordyreetikk. no/1997/06/skille-melkeku-kalv/

Tine Rådgiving (2013) Faglig rapport KU 2012, (Professional report cow 2012, in Norwegian), TINE Midt-Norge, Oslo, $36 \mathrm{p}$

Tine Rådgiving (2014) Årsrapport for helsekortordningen 2013, helsekortordningen, storfe 2013 - statistikksamling, (Annual health recording report 2013, in Norwegian), URL: http://storfehelse.tine. no/om-oss $/ \%$ C 3\% A 5 rsmeldinger-og-rapporter/\% C3\% A5rsrapporter-for-helsekortordningen, $23 \mathrm{p}$

Ventura BA, von Keyserlingk MAG, Schuppli CA, Weary DM (2013) Views on contentious practices in dairy farming: the case of early cow-calf separation. J Dairy Sci 96(9):6105-6116

von Keyserlingk MAG, Weary DM (2007) Maternal behavior in cattle. Horm Behav 52(1):106-113

von Keyserlingk MAG, Martin NP, Kebreab E, Knowlton KF, Grant RJ, Stephenson M, Sniffen CJ, Harner JR, Wright AD, Smith SI (2013) Invited review: sustainability of the US dairy industry. J Dairy Sci 96(9):5405-5425

Wagenaar JPJL, Langhout J (2007) Practical implications of increasing 'natural living' through suckling systems in organic dairy calf rearing. Neth J Agric Sci 54(4):375-386

Wagner K, Barth K, Hillmann H, Palme R, Futschik A, Waiblinger S (2013) Mother rearing of dairy calves: reactions to isolation and to confrontation with an unfamiliar conspecific in a new environment. Appl Anim Behav Sci 147(1-2):43-54

Weary DM, Chua B (2000) Effects of early separation on the dairy cow and calf: 1 . Separation at $6 \mathrm{~h}, 1$ day and 4 days after birth. Appl Anim Behav Sci 69(3):177-188

Weary DM, Jasper J, Hötzel MJ (2008) Understanding weaning distress. Appl Anim Behav Sci 110(1-2):24-41

Wyatt RD, Gould MD, Totusek R (1977) Effects of single versus simulated twin rearing on cow and calf performance. J Anim Sci 45(6): 1409-1414

Zipp KA, Barth K, Knierim U (2013) Milchleistung, Milchfluss und Milchinhaltsstoffe von Kühen mit und ohne Kalbkontakt in Abhängigkeit von verschiedenen Stimulationsverfahren beim Melken, in: Neuhoff D., Stumm C., Ziegler S., Rahmann G., Hamm U., Köpke U. (Eds.), 12 Wissenschaftstagung Ökologischer Landbau, Ideal und Wirklichkeit - Perspektiven Ökologischer Landbewirtschaftung, in German, Rheinische Friedrich-WilhelmsUniversität, March 5-8, Bonn, Germany, 462-465, Köster, Berlin, http://orgprints.org/21502 